\title{
KONTRIBUSI IMPLEMENTASI MANAJEMEN SEKOLAH BERBASIS NILAI-NILAI KEARIFAN LOKAL TRI HITA KARANA, KEPEMIMPINAN PELAYAN KEPALA SEKOLAH, BUDAYA SEKOLAH, DAN KEPUASAN KERJA TERHADAP KINERJA GURU DI SMP NEGERI KECAMATAN SUKASADA KABUPATEN BULELENG
}

\author{
Ni Putu Aryantini, Anak. Agung. Gede Agung, Kadek Rihendra Dantes \\ Program Studi Administrasi Pendidikan, Program Pascasarjana \\ Universitas Pendidikan Ganesha \\ Singaraja, Indonesia
}

e-mail: putuaryantini23@gmail.com,gede.agung@pasca.undiksha.ac.id, rihendra-

dantes@undiksha.ac.id

\begin{abstract}
ABSTRAK
Penelitian ini dilatarbelakangi oleh rendahnya kinerja guru seperti rata-rata UKG Nasional tahun 2015 hanya 53,02 dan hasil UTN dari PLPG tahun 2017 hanya 44 \% yang lulus, dimana hal ini dipengaruhi oleh faktor eksternal dan faktor internal. Faktor eksternalnya adalah implementasi manajemen sekolah berbasis nilai-nilai kearifan lokal Tri Hita Karana, kepemimpinan pelayan kepala sekolah, dan budaya sekolah. Faktor internalnya adalah kepuasan kerja. Penelitian ini bertujuan untuk mengetahui kontribusi implementasi manajemen sekolah berbasis nilai-nilai kearifan lokal Tri Hita Karana, kepemimpinan pelayan kepala sekolah, budaya sekolah, dan kepuasan kerja terhadap kinerja guru di SMP Negeri Kecamatan Sukasada Kabupaten Buleleng. Penelitian ini merupakan jenis penelitian ex-post facto dengan desain penelitian deskriptif dan korelasional. Penelitian ini termasuk studi populasi yaitu 110 orang guru PNS. Metode pengumpulan data dengan kuesioner. Untuk menganalisis data digunakan teknik analisis deskriptif dan teknik analisis jalur (path analysis). Hasil penelitian menunjukkan bahwa: kondisi kinerja guru berada pada kategori sangat baik $(82,73 \%)$, manajemen sekolah berbasis nilai-nilai kearifan lokal Tri Hita Karana pada kategori baik $(82,73 \%)$, kepemimpinan pelayan kepala sekolah pada kategori sangat baik $(74,55 \%)$, budaya sekolah pada kategori baik $(88,18 \%)$, dan kepuasan kerja pada kategori sangat baik $75,45 \%$ ). Serta (1) ada kontribusi secara langsung yang signifikan implementasi manajemen sekolah berbasis nilai-nilai kearifan lokal Tri Hita Karana terhadap kepuasan kerja guru dengan koefisien jalur 0,295; (2) ada kontribusi secara langsung yang signifikan kepemimpinan pelayan kepala sekolah terhadap kepuasan kerja guru dengan koefisien jalur 0,404; (3) ada kontribusi secara langsung budaya sekolah terhadap kepuasan kerja guru dengan koefisien jalur 0,170 ; (4) ada kontribusi secara langsung yang signifikan implementasi manajemen sekolah berbasis nilai-nilai kearifan lokal Tri Hita Karana terhadap kinerja guru dengan koefisien jalur 0,321 ; (5) ada kontribusi secara langsung yang signifikan kepemimpinan pelayan kepala sekolah terhadap kinerja guru dengan koefisien jalur 0,156 ; (6) ada kontribusi secara langsung yang signifikan budaya sekolah terhadap kinerja guru dengan koefisien jalur 0,255 ; (7) ada kontribusi secara langsung yang signifikan kepuasan kerja terhadap kinerja guru dengan koefisien jalur 0,383; (8) ada kontribusi secara tidak langsung yang signifikan implementasi manajemen sekolah berbasis nilai-nilai kearifan lokal Tri Hita Karana terhadap kinerja guru melalui kepuasan kerja dengan koefisien jalur 0,295 dan 0,383; (9) ada kontribusi secara tidak langsung yang signifikan kepemimpinan pelayan kepala sekolah terhadap kinerja guru melalui kepuasan kerja dengan koefisien jalur 0,404 dan 0,383; (10) ada kontribusi secara tidak langsung yang signifikan budaya
\end{abstract}


sekolah terhadap kinerja guru melalui kepuasan kerja dengan koefisien jalur 0,170 dan 0,383; (11) ada kontribusi secara simultan yang signifikan implementasi manajemen sekolah berbasis nilai-nilai kearifan lokal Tri Hita Karana, kepemimpinan pelayan kepala sekolah, dan budaya sekolah terhadap kinerja guru melalui kepuasan kerja dengan koefisien jalur 0,$295 ; 0,404 ; 0,170 ; 0,383 ;$ (12) ada kontribusi secara simultan yang signifikan implementasi manajemen sekolah berbasis nilai-nilai kearifan lokal Tri Hita Karana, kepemimpinan pelayan kepala sekolah, budaya sekolah, dan kepuasan kerja terhadap kinerja guru sebesar 0,619 (61,9\%) dengan koefisien jalur 0,$321 ; 0,156 ; 0,255$; dan 0,383 .

Kata kunci: manajemen sekolah berbasis nilai-nilai kearifan lokal tri hita karana, kepemimpinan pelayan kepala sekolah, budaya sekolah, kepuasan kerja, dan kinerja guru

\begin{abstract}
This research is motivated by the low performance of teachers such as the UKG national average of 2015 only 53.02 and the UTN results from PLPG 2017 only 44\% graduated, which is influenced by external factors and internal factors. External factors are the implementation of school management based on local wisdom values Tri Hita Karana, headmaster's leadership of service, and school culture. Internal factor is job satisfaction. This study was aimed to determine the contribution of school management based on local wisdom values of Tri Hita Karana, headmaster's leadership of service, school culture, and job satisfaction of teacher's performance in SMP Negeri Sukasada district, Buleleng regency. This research was a kind of ex-post facto research with descriptive and correlational research design. This research was population study as 110 government teachers. Method of data collection was by questionnaire. To analyze the data used descriptive analysis techniques and path analysis techniques (path analysis). The result of this research showed that: the teacher performance's condition was in very good category $(82,73 \%)$, the school management based on local wisdom values of Tri Hita Karana in good category $(82,72 \%)$, headmaster's leadership of service was in very good category $(74,55$ $\%)$, the school culture was in the good category $(88,18 \%)$, and the job satisfaction was in the very category good $(75,45 \%)$. As well as (1) there was a significant direct contribution the implementation of school management based on local wisdom values of Tri Hita Karana on teacher's work satisfaction with path coefficient 0,295 ; (2) there was a significant direct contribution headmaster's leadership of service towards teacher work satisfaction with path coefficient 0,404 ; (3) there was a direct contribution school culture to teacher work satisfaction with path coefficient 0,170 ; (4) there was a significant direct contribution the implementation of school management based on local wisdom values of Tri Hita Karana to teacher performance with path coefficient 0,321 ; (5) there was a significant direct contribution headmaster's leadership of service to teacher performance with path coefficient 0,156 ; $(6)$ there was a significant direct contribution school culture to teacher performance with path coefficient 0,$255 ;(7)$ there was a significant direct contribution job satisfaction and teacher performance with path coefficient 0,383 ; (8) there was a significant indirect contribution the implementation of school management based on local wisdom values of Tri Hita Karana towards performance of teachers through job satisfaction with path coefficient 0,295 and 0,383; (9) there was a significant indirect contribution headmaster's leadership of service on teacher performance through job satisfaction with path coefficient 0,404 and 0,383; (10) there was a significant indirect contribution school culture on teacher performance through job satisfaction with path coefficient 0,170 and 0,383 ; (11) ) there was a significant simultaneous contribution the implementation of school management based on local wisdom values of Tri Hita Karana, headmaster's leadership of service, and school culture on teacher performance through job satisfaction with path coefficient 0,$295 ; 0,404$; 0,$170 ; 0,383$; (12) there was a significant simultaneous contribution the implementation of
\end{abstract}


school-based management the local wisdom values of Tri Hita Karana, headmaster's leadership of service, the school culture, and job satisfaction on teacher performance amount $0,619(61,9 \%)$ with path coefficient 0,$321 ; 0,156 ; 0,255$; and 0,383 .

Keywords: school management based on local wisdom values of Tri Hita Karana, headmaster's leadership of service, school culture, job satisfaction, and teacher's performance.

\section{PENDAHULUAN}

Pendidikan merupakan hal yang sangat penting di era globalisasi ini karena pendidikan menjadi salah satu penentu mutu Sumber Daya Manusia. Keunggulan suatu bangsa tidak lagi ditandai dengan melimpahnya sumber kekayaan alam, melainkan adanya keunggulan Sumber Daya Manusia (SDM). Sumber Daya Manusia (SDM) sangat berhubungan erat dengan mutu pendidikan, dimana mutu pendidikan yang dimaksud berada pada kondisi yang baik, memenuhi syarat, dengan berbagai komponen terdapat didalamnya seperti masukan, proses, keluaran, komitmen sekolah, budaya sekolah, kepemimpinan kepala sekolah, tenaga kependidikan, sarana dan prasarana serta biaya, dan lain sebagainya.

Keberhasilan suatu sekolah dalam menciptakan pendidikan yang berkualitas sangat didukung oleh berbagai variabel seperti manajemen sekolah, kepemimpinan kepala sekolah, budaya sekolah, kepuasan kerja sampai pada kinerja dari seorang guru.

Kenyataannya bahwa kinerja guru masih cukup rendah dengan bukti rata-rata UKG Nasional tahun 2015 hanya 53,02 (Dapodik, 2015:2) dan hasil UTN dari PLPG tahun 2017 hanya $44 \%$ yang lulus (Dapodik, 2017:1). Hal ini dipengaruhi oleh faktor eksternal dan faktor internal. Faktor eksternalnya seperti implementasi manajemen sekolah berbasis nilai-nilai kearifan lokal Tri Hita Karana, kepemimpinan pelayan kepala sekolah, dan budaya sekolah dan faktor internalnya seperti kepuasan kerja.

Berdasarkan berbagai faktor diatas maka dalam penelitian ini apakah terdapat kontribusi secara langsung yang signifikan antara implementasi manajemen sekolah berbasis nilai-nilai kearifan lokal Tri Hita Karana terhadap kepuasan kerja, apakah terdapat kontribusi secara langsung yang signifikan antara kepemimpinan pelayan kepala sekolah terhadap kepuasan kerja, apakah terdapat kontribusi secara langsung antara budaya sekolah terhadap kepuasan kerja, apakah terdapat kontribusi secara langsung yang signifikan antara implementasi manajemen sekolah berbasis nilai-nilai kearifan lokal Tri Hita Karana terhadap kinerja guru, apakah terdapat kontribusi secara langsung yang signifikan antara kepemimpinan pelayan kepala sekolah terhadap kinerja guru, apakah terdapat kontribusi secara langsung antara budaya sekolah terhadap kinerja guru, apakah terdapat kontribusi secara langsung yang signifikan antara kepuasan kerja terhadap kinerja guru, apakah terdapat kontribusi secara tidak langsung yang signifikan antara implementasi manajemen sekolah berbasis nilai-nilai kearifan lokal Tri Hita Karana terhadap kinerja guru melalui kepuasan kerja, apakah terdapat kontribusi secara tidak langsung yang signifikan antara kepemimpinan pelayan kepala sekolah terhadap kinerja guru melalui kepuasan kerja, apakah terdapat kontribusi secara tidak langsung yang signifikan antara budaya sekolah terhadap kinerja guru melalui kepuasan kerja. apakah terdapat kontribusi secara simultan yang signifikan antara implementasi manajemen sekolah berbasis nilai-nilai kearifan lokal Tri Hita Karana, kepemimpinan pelayan kepala sekolah, dan budaya sekolah terhadap kinerja guru melalui kepuasan kerja, apakah terdapat kontribusi secara simultan yang signifikan antara implementasi manajemen sekolah berbasis nilai-nilai kearifan lokal Tri Hita Karana, kepemimpinan pelayan kepala sekolah, budaya sekolah, dan kepuasan kerja terhadap kinerja guru.

Kinerja guru yang diharapkan bisa mendukung keberhasilan pendidikan apabila memenuhi berbagai aspek sesuai dengan yang diatur Undang-Undang Republik Indonesia Nomor 20 Tahun 2003 tentang Sistem Pendidikan Nasional pasal 39 ayat (2), Undang 
Undang Nomor 14 Tahun 2005 Bab IV Pasal 20 (a) tentang Guru dan Dosen, dan Peraturan Menteri Pendidikan Nasional Nomor 41 Tahun 2007 tentang Standar Proses untuk Satuan Pendidikan Dasar dan Menengah, dimana kinerja guru mencakup 5 aspek yaitu (1) perencanaan proses pembelajaran; (2) pelaksanaan proses pembelajaran; (3) penilaian hasil pembelajaran; (4) pembimbingan dan pelatihan peserta didik; (5) pengawasan proses pembelajaran; (6) pelaksanaan tugas tambahan.

Manajemen sekolah yang diharapkan bisa mendukung keberhasilan proses pendidikan adalah manajemen yang mengintegrasikan ajaran Tri Hita Karana dengan peraturan dan perundang-undangan. Adanya kaitan antara Peraturan Menteri Pendidikan Nasional Nomor 19 Tahun 2007 tentang Standar Pengelolaan Pendidikan yang dalam hal ini terdiri dari (1) manajemen kesiswaan, (2) manajemen kurikulum, (3) manajemen pendidik dan tenaga kependidikan, (4) manajemen sarana dan prasarana, (5) manajemen keuangan dan pembiayaan, dengan konsep Tri Hita Karana yang terdiri dari (1) aspek parahyangan, (2) aspek pawongan, dan (3) aspek palemahan.

Kepala sekolah sebagai pemegang kebijakan pendidikan di sekolah memiliki peran yang sangat penting. Kepala sekolah diharapkan memiliki sifat kepemimpinan pelayan yang menurut Greenleaf, 1999 (dalam Mulyadi, 2015:166) memiliki 10 ciri khas atau dimensi yaitu : (1) mendengarkan, (2) empati, (3) menyembuhkan, (4) kesadaran, (5) bujukan atau persuasif, (6) konseptualisasi, (7) kemampuan meramalkan, (8) kemampuan melayani, (9) komitmen kepada pertumbuhan manusia, (10) membangun masyarakat.

Selanjutnya bahwa budaya yang terjadi di sekolah juga tidak bisa dilepaskan sebagai faktor penentu keberhasilan pendidikan. Budaya sekolah yang diharapkan adalah sesuai dengan teori dari Owens (1991), Sonhadji (1991); Creemers \& Reynold (1993); Greenberg dan Baron (1995). Dari teori-teori tersebut, dapat dideskripsikan 12 dimensi variabel budaya organisasi yang terdiri dari: (1) nilai-nilai, (2) keteladanan, (3) tanggung jawab, (4) kebersamaan/ intimasi, (5) otonomi individu, (6) norma/tata aturan, (7) dukungan, (8) identitas, (9) hadiah performansi, (10) toleransi konflik, (11) toleransi risiko, (12) upacara simbolik.

Semua variabel diatas jika dilaksanakan dengan baik maka pada akhirnya akan menciptakan suatu kepuasan kerja tersendiri dari berbagai komponen yang ada di sekolah seperti guru, tenaga pendidik dan kependidikan serta siswa itu sendiri. Adanya kepuasan kerja guru akan bermuara pada kinerja yang maksimal dari guru itu sendiri. Indikator kepuasan kerja guru menggunakan teori dari Robbins (1996:180) dan Luthans (2002:230), yang mendeskripsikan ada 12 dimensi variabel kepuasan kerja yang terdiri atas: (1) organisasi kerja, (2) kondisi kerja, (3) komunikasi, (4) kinerja pekerjaan dan tinjauan ulang kinerja, (5) rekan sekerja, (6) penyeliaan, (7) manajemen perusahaan, (8) upah, (9) tunjangan, (10) pengembangan karir dan pelatihan, (11) isi dan kepuasan pekerjaan, (12) citra lembaga dan perubahan.

Pelaksanaan semua variabel yakni manajemen sekolah berbasis Tri Hita Karana, kepemimpinan pelayan kepala sekolah, budaya sekolah, dan kepuasan kerja akan membuat kinerja guru menjadi maksimal. Hal ini didukung oleh berbagai penelitian terdahulu yang meneliti berbagai variabel diatas. Penelitian Agung (2017) dalam penelitian berjudul "Developing School Management Model Based on Balinese Local Wisdom" atau Pengembangan Model Manajemen Sekolah Berdasarkan Kebijaksanaan Lokal Bali. Werang dan Agung (2017) dalam penelitian berjudul "Teachers' Job Satisfaction, Orga-nizational Commit-ment, and Perfor-mance In Indonesia: A Study From Merauke District, Papua" atau Kepuasan kerja guru, komitmen organisasi, dan kinerja di Indonesia: Studi dari Kabupaten Merauke, Papua. Joshua H. L. Tobing (2016) dalam penelitiannya berjudul "Kepemimpinan Sekolah, Budaya, Strategi dan Kinerja Guru". Mahmudah Enny W (2015) meneliti tentang "Pengaruh SMM ISO 9001-2008, Total Quality Management dan lingkungan kerja pada pekerjaan kepuasan dan kinerja karyawan di PT Mount Dreams Indonesia di Gresik". Jajang W Mahri (2014) dalam penelitiannya tentang "Kepemimpinan Kepala Sekolah, Pengaruhnya terhadap Kompetensi, Motivasi dan Kepuasan Kerja Guru serta Implikasinya pada Kinerja Guru". Endang Tirtana Putra dan Yelvia Yunita (2014) dalam penelitiannya berjudul "Pengaruh Kepemimpinan Kepala Sekolah dan Budaya Organisasi terhadap Kinerja Guru 
SMA Negeri 1 Simpang Empat". Suhaemi Suleman (2016) meneliti tentang "Pengaruh Gaya Kepemimpinan Kepala Sekolah, Budaya Sekolah, Dan Disiplin Guru Terhadap Kinerja Guru Pada Sekolah Menengah Kejuruan (Smk) Negeri I Jeneponto". Titik Handayani, Aliyah A. Rasyid (2015) dalam penelitian berjudul "Pengaruh Kepemimpinan Kepala Sekolah, Motivasi Guru, Dan Budaya Organisasi Terhadap Kinerja Guru SMA Negeri Wonosobo". Abidin (2015) dalam suatu penelitian yang berjudul "Pengaruh Gaya Kepemimpinan Kepala Sekolah, Kepuasan Kerja, Dan Komitmen Organisasi Dalam Meningkatkan Kinerja Guru Sekolah Dasar Di Kecamatan Sangia Ambulu Kabupaten Buton". Febry Zakharia (2014) dalam penelitiannya berjudul "Pengaruh Budaya Organisasi Dan Kepuasan Kerja Terhadap Kinerja Guru SMP Yadika 3 Tangerang". Sudira (2012) meneliti tentang "Praksis Tri Hita Karana Dalam Struktur Dan Kultur Pendidikan Karakter Kejuruan Pada Smk Di Bali". Kemananda (2015) meneliti tentang "Kontribusi Perilaku Kepemimpinan Kepala Sekolah, Budaya Organisasi dan Komitmen Kerja terhadap Kinerja Guru SD Gugus VII Kecamatan Mengwi”. Yasmini (2015) meneliti tentang "Kontribusi Gaya Kepemimpinan Kepala Sekolah, Kompetensi Profesional dan Motivasi Kerja Guru Terhadap Kinerja Guru-Guru Sekolah Dasar di Kecamatan Kuta Utara". Suartini (2013) meneliti tentang "Kontribusi Komitmen Kerja, Kepemimpinan Kepala Lembaga dan Lingkungan Kerja terhadap Kinerja Pendidikan PAUD (studi pada lembaga PUD di Kuta Utara Kabupaten badung tahun pelajaran 2012/2013)". Mukasari (2014) meneliti tentang "Determinasi Persepsi Guru tentang Kemampuan Manajerial Kepala Sekolah, Iklim Kerja sekolah, Motivasi Kerja terhadap Kinerja Guru di SMA Kabupaten Kutapura Kuta".

Sehingga berdasarkan berbagai teori dan penelitian terdahulu maka diperoleh hasil adanya kontribusi antara manajemen sekolah berbasis Tri Hita Karana, kepemimpinan pelayan kepala sekolah, budaya sekolah, dan kepuasan kerja terhadap kinerja guru. Maka hipotesis dalam penelitian ini adalah sebagai berikut: 1). Ada kontribusi secara langsung yang signifikan implementasi manajemen sekolah berbasis nilai-nilai kearifan lokal Tri Hita Karana $\left(X_{1}\right)$ terhadap kepuasan kerja $\left(X_{4}\right)$ guru di SMP Negeri Kecamatan Sukasada Kabupaten Buleleng; 2) Ada kontribusi secara langsung yang signifikankepemimpinan pelayan kepala sekolah $\left(X_{2}\right)$ terhadap kepuasan kerja $\left(X_{4}\right)$ guru di SMP Negeri Kecamatan Sukasada Kabupaten Buleleng; 3) Ada kontribusi secara langsung budaya sekolah $\left(X_{3}\right)$ terhadap kepuasan kerja $\left(X_{4}\right)$ guru di SMP Negeri Kecamatan Sukasada Kabupaten Buleleng; 4) Ada kontribusi secara langsung yang signifikan implementasi manajemen sekolah berbasis nilai-nilai kearifan lokal Tri Hita Karana $\left(\mathrm{X}_{1}\right)$ terhadap kinerja guru $(\mathrm{Y})$ di SMP Negeri Kecamatan Sukasada Kabupaten Buleleng, 5) Ada kontribusi secara langsung yang signifikan kepemimpinan pelayan kepala sekolah $\left(\mathrm{X}_{2}\right)$ terhadap kinerja guru $(\mathrm{Y})$ di SMP Negeri Kecamatan Sukasada Kabupaten Buleleng; 6) Ada kontribusi secara langsung budaya sekolah $\left(\mathrm{X}_{3}\right)$ terhadap kinerja guru (Y) di SMP Negeri Kecamatan Sukasada Kabupaten Buleleng, 7) Ada kontribusi secara langsung yang signifikan kepuasan kerja $\left(X_{4}\right)$ terhadap kinerja guru (Y) di SMP Negeri Kecamatan Sukasada Kabupaten Buleleng, 8) Ada kontribusi secara tidak langsung yang signifikan implementasi manajemen sekolah berbasis nilai-nilai kearifan lokal Tri Hita Karana $\left(\mathrm{X}_{1}\right)$ terhadap kinerja guru (Y) melalui kepuasan kerja $\left(\mathrm{X}_{4}\right)$ di SMP Negeri Kecamatan Sukasada Kabupaten Buleleng; 9) Ada kontribusi secara tidak langsung yang signifikan kepemimpinan pelayan kepala sekolah $\left(\mathrm{X}_{2}\right)$ terhadap kinerja guru $(\mathrm{Y})$ melalui kepuasan kerja $\left(\mathrm{X}_{4}\right)$ di SMP Negeri Kecamatan Sukasada Kabupaten Buleleng; 10) Ada kontribusi secara tidak langsung yang signifikan budaya sekolah $\left(\mathrm{X}_{3}\right)$ terhadap kinerja guru $(\mathrm{Y})$ melalui kepuasan kerja $\left(\mathrm{X}_{4}\right)$ di SMP Negeri Kecamatan Sukasada Kabupaten Buleleng; 11) Ada kontribusi secara simultan yang signifikan implementasi manajemen sekolah berbasis nilai-nilai kearifan lokal Tri Hita Karana $\left(X_{1}\right)$, kepemimpinan pelayan kepala sekolah $\left(X_{2}\right)$, dan budaya sekolah $\left(\mathrm{X}_{3}\right)$ terhadap kinerja guru $(\mathrm{Y})$ melalui kepuasan kerja $\left(\mathrm{X}_{4}\right)$ di SMP Negeri Kecamatan Sukasada Kabupaten Buleleng; 12) Ada kontribusi secara simultan yang signifikan implementasi manajemen sekolah berbasis nilai-nilai kearifan lokal Tri Hita Karana $\left(X_{1}\right)$, kepemimpinan pelayan kepala sekolah $\left(X_{2}\right)$, budaya sekolah $\left(X_{3}\right)$, 
dan kepuasan kerja $\left(\mathrm{X}_{4}\right)$ terhadap kinerja guru $(\mathrm{Y})$ di SMP Negeri Kecamatan Sukasada Kabupaten Buleleng.

\section{METODE PENELITIAN}

Rancangan penelitian yang digunakan dalam penelitian ini tergolong penelitian ex post facto dengan desain penelitian deskriptif dan korelasional. Penelitian ex post facto merupakan suatu pendekatan pada subjek penelitian untuk meneliti yang telah dimiliki oleh subjek penelitian secara wajar tanpa adanya usaha sengaja memberikan perlakuan untuk memunculkan variabel yang ingin diteliti, dan desain penelitian ex post facto terdiri dari korelasional dan komparatif (Dantes, 2012:59). Dikatakan penelitian deskriptif dikarenakan peneliti berusaha memperoleh informasi yang berkenaan dengan fenomena yang diamati saat ini selanjutnya mendeskripsikan data tentang objek atau variabel yang diteliti (Dantes, 2012:51). Dikatakan penelitian korelasional dikarenakan peneliti ingin menjelaskan hubungan atau korelasi antara berbagai variabel berdasarkan besar kecilnya koefisien korelasi (Ardhana, 1987:33).

Populasi dalam penelitian ini adalah seluruh guru SMP Negeri Kecamatan Sukasada Kabupaten Buleleng terdiri atas 110 orang guru PNS yang kesemuanya sekaligus dijadikan sampel penelitian. Adapun alasan digunakan guru PNS adalah (1) guru Non PNS biasanya (kebanyakan) datang ke sekolah hanya pada saat mengajar saja, (2) dengan terbatasnya keberadaan guru Non PNS tersebut di sekolah maka mereka tidak terlalu memahami tentang manajemen sekolah, kepemimpinan kepala sekolah dan budaya organisasi yang terjadi di sekolah, (3) persepsi guru tentang manajemen sekolah, kepemimpinan kepala sekolah, budaya sekolah, kepuasan kerja, dan kinerja guru akan memerlukan kontinuitas dan intensitas psikologis yang tinggi, dalam hal ini hanya bisa dilakukan oleh guru tetap/PNS yang secara kontinyu mengetahui, mengalami, dan menghayati keberadaan sekolah dan kepala sekolahnya serta manajemen sekolah.

Dalam penelitian ini menggunakan tiga variabel yaitu variabel bebas (independent variable) atau eksogenous, variabel moderator atau intervening, dan variabel terikat (dependent variable) atau endogenous. Variabel bebasnya yaitu implementasi manajemen sekolah berbasis nilai-nilai kearifan lokal Tri Hita Karana $\left(\mathrm{X}_{1}\right)$, kepemimpinan pelayanan kepala sekolah $\left(\mathrm{X}_{2}\right)$, dan budaya sekolah $\left(\mathrm{X}_{3}\right)$. Variabel moderatornya yaitu kepuasan kerja $\left(\mathrm{X}_{4}\right)$. Variabel terikatnya yaitu kinerja guru (Y) di SMP Negeri Kecamatan Sukasada Kabupaten Buleleng.

Definisi Operasional kinerja guru adalah hasil kerja seorang guru selama periode tertentu yang terdiri dari (1) perencanaan proses pembelajaran, (2) pelaksanaan proses pembelajaran, (3) penilaian hasil pembelajaran, (4) pembimbingan dan pelatihan peserta didik, (5) pengawasan proses pembelajaran, dan (6) pelaksanaan tugas tambahan untuk menghasilkan kinerja yang optimal terutama di sekolah. Implementasi Manajemen Sekolah Berbasis Nilai-Nilai Kearifan Lokal Tri Hita Karana adalah manajemen yang diterapkan disekolah dengan berbasis pada nilai-nilai kearifan lokal Tri Hita Karana yang terdiri dari (1) manajemen kesiswaan berbasis parahyangan, pawongan, dan palemahan, (2) manajemen kurikulum berbasis parahyangan, pawongan, dan palemahan, (3) manajemen pendidik dan tenaga kependidikan berbasis parahyangan, pawongan, dan palemahan, (4) manajemen sarana dan prasarana berbasis parahyangan, pawongan, dan palemahan, (5) manajemen keuangan dan pembiayaan berbasis parahyangan, pawongan, dan palemahan. Kepemimpinan pelayan kepala sekolah adalah gaya kepemimpinan yang dimiliki oleh seorang kepala sekolah yang terdiri dari (1) mendengarkan, (2) empati, (3) menyembuhkan, (4) kesadaran, (5) bujukan/persuasif, (6) konseptualisasi, (7) kemampuan meramalkan, (8) kemampuan melayani, (9) komitmen kepada pertumbuhan manusia, (10) membangun masyarakat, (11) kerelaan dalam menerima kewajiban, (12) kasih yang penuh perhatian, (13) rendah hati, (14) rela berbagi dalam kekuasaan. Budaya organisasi sekolah adalah norma perilaku, nilainilai dan kebiasaan yang menggambarkan kepribadian organsiasi sekolah yang diukur melalui dimensi (1) nilai-nilai, (2) keteladanan, (3) tanggung jawab, kebersamaan/intimasi, (5) otonomi individu, (6) norma/tata aturan, (7) dukungan, (8) 
identitas, (9) hadiah performansi, (10) toleransi konflik, (11) toleransi risiko, (12) upacara simbolik. Kepuasan kerja adalah perasaan individu yang berkaitan dengan sejauh mana kebutuhannya terpenuhi melalui pengalaman dalam situasi pekerjaan yang terdiri dari (1) organisasi kerja, (2) kondisi kerja, (3) komunikasi, (4) kinerja pekerjaan dan tinjauan ulang kinerja, (5) rekan sekerja, (6) penyeliaan, (7) manajemen perusahaan, (8) upah, (9) tunjangan, (10) pengembangan karir dan pelatihan, (11) isi dan kepuasan pekerjaan, dan (12) citra lembaga dan perubahan. Semua variabel diukur dengan metode kuesioner dan data yang dihasilkan bersifat skor (interval).

Metode pengumpulan data adalah dengan kuesioner. Semua variabel diukur dengan metode kuesioner dan data yang dihasilkan bersifat skor (interval). Instrumen disusun berdasarkan kisi-kisi yang telah ditentukan. Setelah instrumen tersusun maka dilakukan validitas isi oleh pakar manajemen pendidikan. Kemudian instumen diuji coba dan dianalisis validitas menggunakan teknik korelasi Product Moment dari Cari Pearson (Candiasa, 2011:38) yang hasilnya instrumen manajemen sekolah berbasis nilai-nilai kearifan lokal Tri Hita Karana $\left(X_{1}\right)$ yaitu 39 , kepemimpinan pelayan kepala sekolah $\left(X_{2}\right)$ yaitu 37 , budaya sekolah $\left(X_{3}\right)$ yaitu 39 , dan kepuasan kerja $\left(X_{4}\right)$ yaitu 40 , dan kinerja guru (Y) 40. Serta pengujian reliabilitas instrumen menggunakan rumus Alpha Cronbach (Candiasa, 2011:67) yang mendapatkan hasil bahwa semua instrumen yang telah diujicobakan dan memenuhi syarat untuk dapat digunakan sebagai alat pengumpul data dalam rangka penelitian ini, sebab kelima variabel memiliki tingkat reliabilitas yang sangat tinggi.

Kegiatan analisis data terdiri atas kegiatan pengolahan data dan analisis statistik. Kegiatan analisis data meliputi: 1) menyunting data secara manual. Penyuntingan dilakukan karena kemungkinan ada data yang tidak jelas, atau kesalahan dalam pengisian instrument, sehingga tidak memenuhi syarat untuk dianalisis, 2) mentabulasi data, dan 3) mengolah data dalam bentuk sesuai kebutuhan.

Untuk menguji hipotesis yang telah dirumuskan, terlebih dahulu dilakukan analisis data yang telah dikumpulkan. Dalam melakukan analisis data untuk penelitian ini dilakukan dengan tiga tahapan yakni: 1) tahap deskripsi data, 2) tahap pengujian persyarat analisis, 3) tahap pengujian hipotesis.

Data yang telah diperoleh dari penelitian dideskripsikan menurut masing-masing variabel. Oleh tujuannya seperti itu, maka akan dicari harga rerata (M), standar deviasi (SD), modus (Mo), dan median (Me) setiap variabel yang diteliti.

Setelah seluruh uji prasyarat terpenuhi, maka dilanjutkan dengan uji hipotesis. Untuk menganalisis data digunakan teknik analisis deskriptif dan teknik analisis jalur (path analysis) berbantuan program SPSS-22 for windows dan program Liserel 8.7. Dalam hal ini variabel terbagi dalam sejumlah blok yang mempunyai hubungan langsung ataupun tidak langsung dengan variabel terikat. Dalam hal ini Blok 1 mempunyai variabel exogenous implementasi manajemen sekolah berbasis nilai-nilai kearifan lokal Tri Hita Karana, kepemimpinan pelayan kepala sekolah, dan budaya sekolah dengan variabel endogenous kepuasan kerja. Blok 2 sebagai variabel exogenousnya adalah implementasi manajemen sekolah berbasis nilai-nilai kearifan lokal Tri Hita Karana, kepemimpinan pelayan kepala sekolah, budaya sekolah, dan kepuasan kerja dengan variabel endogenousnya adalah kinerja guru. Dan secara keseluruhan antara blok 1 dan blok 2 membentuk sebuah rancangan sebagai berikut.

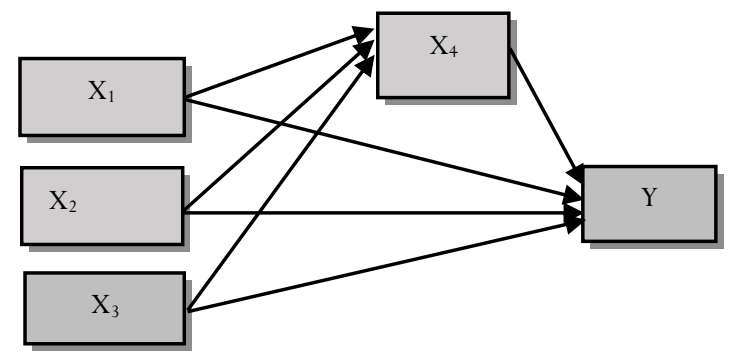




\section{HASIL PENELITIAN DAN PEMBAHASAN}

Hasil analisis deskripsi data ditemukan bahwa pertama, kinerja guru yang diperoleh dari hasil pengukuran terhadap responden menunjukkan berada dalam kategori sangat baik $(82,73 \%)$. Kedua, manajemen sekolah berbasis nilai-nilai kearifan lokal Tri Hita Karana yang diperoleh dari hasil pengukuran terhadap responden menunjukkan berada dalam kategori baik $(82,72 \%)$. Ketiga, kepemimpinan pelayan kepala sekolah yang diperoleh dari hasil pengukuran terhadap responden menunjukkan berada dalam kategori sangat baik $(74,55 \%)$. Keempat, budaya sekolah yang diperoleh dari hasil pengukuran terhadap responden menunjukkan berada dalam kategori baik (88,18\%). Kelima, kepuasan kerja yang diperoleh dari hasil pengukuran terhadap responden menunjukkan berada dalam kategori sangat baik $(75,45 \%)$.

Untuk uji normalitas data dalam penelitian ini dilakukan dengan uji KolmogorovSmirnov dengan bantuan komputer program SPSS-22 for Window dengan nilai probabilitas lebih besar atau sama dengan 0,05 maka data dinyatakan normal, dan sebaliknya jika nilai probabilitas lebih kecil dengan 0,05 maka data dinyatakan tidak normal. Hasil analisis mendapatkan bahwa skor kinerja guru, skor implementasi manajemen sekolah berbasis nilai-nilai kearifan lokal Tri Hita Karana, skor kepemimpinan pelayan kepala sekolah, skor budaya sekolah, dan skor kepuasan kerja berdistribusi normal.

Uji linearitas dilakukan dengan menggunakan bantuan komputer program SPSS-22 for Window. Hasil pengujian mendapatkan F Dev from Linierity dengan sig > 0,05. Didapatkan antara Implementasi manajemen sekolah berbasis nilai-nilai kearifan lokal Tri Hita Karana $\left(X_{1}\right)$, Kepemimpinan pelayan kepala sekolah $\left(X_{2}\right)$, Budaya sekolah $\left(\mathrm{X}_{3}\right)$, Kepuasan kerja $\left(\mathrm{X}_{4}\right)$ dengan Kinerja Guru $(\mathrm{Y})$ mempunyai hubungan yang linier.

Uji autokorelasi menggunakan uji Durbin-Watson dengan bantuan program SPSS-22 for window. Kesimpulan yang didapat adalah pada data penelitian ini tidak terjadi autokorelasi antara manajemen sekolah berbasis Tri Hita Karana $\left(X_{1}\right)$, kepemimpinan pelayan kepala sekolah $\left(\mathrm{X}_{2}\right)$, dan budaya sekolah $\left(\mathrm{X}_{3}\right)$, dan kepuasan kerja $\left(\mathrm{X}_{4}\right)$ terhadap kinerja guru (Y).

Uji heterokedastisitas menggunakan grafik scatter plot dengan bantuan program SPSS-22 for window yaitu dengan melihat pola-pola tertentu pada grafik. Kesimpulan yang didapatkan adalah tidak terjadi masalah heterokedastisitas.

Uji multikolinieritas dapat dilihat dari nilai tolerance dan Variance Inflation Factor (VIF) dengan bantuan program SPSS-22 for window. Nilai tolerance lebih besar dari 0,1 dan nilai VIF lebih kecil 10. Hasil yang didapatkan adalah nilai tolerance lebih besar dari 0,1 dan nilai VIF lebih kecil 10. Kesimpulannya bahwa data

pada variabel penelitian bebas dari multikolinieritas.

Hasil uji hipotesis didapatkan bahwa untuk blok 1 antara $X_{1}, X_{2}, X_{3}$ terhadap $X_{4}$ a) $p_{41}$ $=0,295$ dengan $t_{\text {hitung }}=3,472>t_{\text {tabel }}=0,677$ dan nilai probabilitas $\left.=0,001<\alpha=0,05, b\right) p_{42}=$ 0,404 dengan $t_{\text {hitung }}=4,764>t_{\text {tabel }}=0,677$ dan nilai probabilitas $=0,000<\alpha=0,05$, dan $c$ ) $\mathrm{p}_{43}=0,170$ dengan $\mathrm{t}_{\text {hitung }}=2,231>\mathrm{t}_{\text {tabel }}=0,677$ dan nilai probabilitas $=0,028<\alpha=0,05$. Hasil analisis membuktikan semua koefisien jalur signifikan pada taraf signifikansi $\alpha=0,05$.

Untuk blok 2 didapatkan a) $\mathrm{pY} 1=0,321$ dengan thitung $=4,484>\mathrm{t}_{\text {tabel }}=0,677$ dan nilai probabilitas $=0,000<\alpha=0,05, b)$ pY2 $=0,156$ dengan thitung $=2,098>t_{\text {tabel }}=0,677$ dan nilai probabilitas $=0,038<0,05, \mathrm{c}) \mathrm{pY}_{3}=0,255$ dengan $t_{\text {hitung }}=4,111>t_{\text {tabel }}=0,677$ dan nilai probabilitas $=0,000<0,05$, dan d) $\mathrm{pY} 4=0,383$ dengan thitung $=4,950>t_{\text {tabel }}=0,677$ dan nilai probabilitas $=0,000<0,05$. Hasil analisis membuktikan semua koefisien jalur signifikan pada taraf signifikansi $\alpha=0,05$.

Berdasarkan hasil perhitungan dan pengujian koefisien jalur, dapat diinterpretasikan besarnya kontribusi secara keseluruhan dari masing-masing variabel eksogen dan variabel endogen, maka sesuai dengan keluaran/output program Liserel 8.7 didapatkan gambar berikut. 


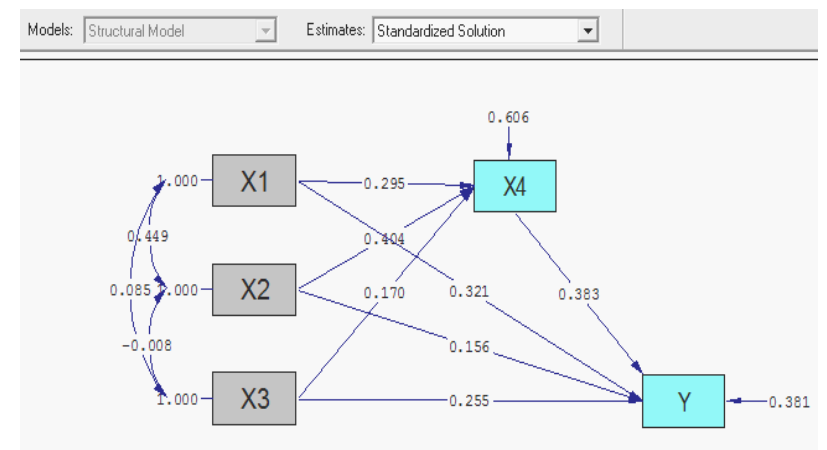

Gambar diatas menunjukkan koefisien jalur antara (1) $X_{1}$ dengan $X_{4}$ adalah 0,295; (2) $\mathrm{X}_{2}$ dengan $\mathrm{X}_{4}$ adalah 0,404 ; (3) $\mathrm{X}_{3}$ dengan $\mathrm{X}_{4}$ adalah 0,170 ; (4) $\mathrm{X}_{1}$ dengan $\mathrm{Y}$ adalah 0,$321 ;(5)$ $X_{2}$ dengan $Y$ adalah 0,156 ; (6) $X_{3}$ dengan $Y$ adalah 0,255 ; (7) $X_{4}$ dengan $Y 0,383 ;(8) X_{1}$ ke $Y$ melalui $X_{4}$ adalah 0,295 dan 0,383; (9) $X_{2}$ ke $Y$ melalui $X_{4}$ adalah 0,404 dan 0,383; (10) $X_{3}$ ke $Y$ melalui $X_{4}$ adalah 0,170 dan 0,$383 ;(11) X_{1}, X_{2}$, dan $X_{3}$ ke $Y$ melalui $X_{4}$ adalah 0,295 ; 0,$404 ; 0,170$; dan 0,383 ; dan (12) $X_{1}, X_{2}, X_{3}$ dan $X_{4}$ ke $Y$ adalah 0,$321 ; 0,156 ; 0,255$; dan 0,383 dengan kontribusi 0,619 (61,9\%). Dengan demikian hipotesis nol (Ho) ditolak dan hipotesis alternatif $(\mathrm{Ha})$ diterima.

Seluruh paparan diatas menunjukkan bahwa teori yang disajikan secara konseptual didukung oleh data yang secara keseluruhan menunjukkan adanya berbagai hubungan.

Kinerja seorang guru selama periode tertentu yang terdiri dari (1) perencanaan proses pembelajaran, (2) pelaksanaan proses pembelajaran, (3) penilaian hasil pembelajaran, (4) pembimbingan dan pelatihan peserta didik, (5) pengawasan proses pembelajaran, dan (6) pelaksanaan tugas tambahan untuk menghasilkan kinerja yang optimal terutama di sekolah.

Implementasi Manajemen Sekolah Berbasis Nilai-Nilai Kearifan Lokal Tri Hita Karana adalah manajemen yang diterapkan disekolah dengan berbasis pada nilainilai kearifan lokal Tri Hita Karana yang terdiri dari (1) manajemen kesiswaan berbasis parahyangan, pawongan, dan palemahan, (2) manajemen kurikulum berbasis parahyangan, pawongan, dan palemahan, (3) manajemen pendidik dan tenaga kependidikan berbasis parahyangan, pawongan, dan palemahan, (4) manajemen sarana dan prasarana berbasis parahyangan, pawongan, dan palemahan, (5) manajemen keuangan dan pembiayaan berbasis parahyangan, pawongan, dan palemahan.

Kepemimpinan pelayan kepala sekolah adalah gaya kepemimpinan yang dimiliki oleh seorang kepala sekolah yang terdiri dari (1) mendengarkan, (2) empati, (3) menyembuhkan, (4) kesadaran, (5) bujukan/persuasif, (6) konseptualisasi, (7) kemampuan meramalkan, (8) kemampuan melayani, (9) komitmen kepada pertumbuhan manusia, (10) membangun masyarakat, (11) kerelaan dalam menerima kewajiban, (12) kasih yang penuh perhatian, (13) rendah hati, (14) rela berbagi dalam kekuasaan.

Budaya organisasi sekolah adalah norma perilaku, nilai-nilai dan kebiasaan yang menggambarkan kepribadian organsiasi sekolah yang diukur melalui dimensi (1) nilai-nilai, (2) keteladanan, (3) tanggung jawab, (4) kebersamaan/intimasi, (5) otonomi individu, (6) norma/tata aturan, (7) dukungan, (8) identitas, (9) hadiah performansi, (10) toleransi konflik, (11) toleransi risiko, (12) upacara simbolik.

Kepuasan kerja adalah perasaan individu yang berkaitan dengan sejauh mana kebutuhannya terpenuhi melalui pengalaman dalam situasi pekerjaan yang terdiri dari (1) organisasi kerja, (2) kondisi kerja, (3) komunikasi, (4) kinerja pekerjaan dan tinjauan ulang kinerja, (5) rekan sekerja, (6) penyeliaan, (7) manajemen perusahaan, (8) upah, (9) tunjangan, (10) pengembangan karir dan pelatihan, (11) isi dan kepuasan pekerjaan, dan (12) citra lembaga dan perubahan. Semua variabel diukur dengan metode kuesioner dan data yang dihasilkan bersifat skor (interval). 


\section{PENUTUP}

Berdasarkan analisis dan pembahasan maka kesimpulan yang didapat adalah sebagai berikut. (1) Ada kontribusi secara langsung yang signifikan implementasi manajemen sekolah berbasis nilai-nilai kearifan lokal Tri Hita Karana terhadap kepuasan kerja. (2) Ada kontribusi secara langsung yang signifikan kepemimpinan pelayan kepala sekolah terhadap kepuasan kerja. (3) Ada kontribusi secara langsung budaya sekolah terhadap kepuasan kerja. (4) Ada kontribusi secara langsung yang signifikan implementasi manajemen sekolah berbasis nilai-nilai kearifan lokal Tri Hita Karana terhadap kinerja guru. (5) Ada kontribusi secara langsung yang signifikan kepemimpinan pelayan kepala sekolah terhadap kinerja guru. (6) Ada kontribusi secara langsung budaya sekolah terhadap kinerja guru. (7) Ada kontribusi secara langsung yang signifikan kepuasan kerja terhadap kinerja guru. (8) Ada kontribusi secara tidak langsung yang signifikan implementasi manajemen sekolah berbasis nilai-nilai kearifan lokal Tri Hita Karana terhadap kinerja guru melalui kepuasan kerja. (9) Ada kontribusi secara tidak langsung yang signifikan kepemimpinan pelayan kepala sekolah terhadap kinerja guru melalui kepuasan kerja. (10) Ada kontribusi secara tidak langsung yang signifikan budaya sekolah terhadap kinerja guru melalui kepuasan kerja. (11) Ada kontribusi secara simultan yang signifikan implementasi manajemen sekolah berbasis nilai-nilai kearifan lokal Tri Hita Karana, kepemimpinan pelayan kepala sekolah, dan budaya sekolah terhadap kinerja guru melalui kepuasan kerja. (12) Ada kontribusi secara simultan yang signifikan implementasi manajemen sekolah berbasis nilai-nilai kearifan lokal Tri Hita Karana, kepemimpinan pelayan kepala sekolah, budaya sekolah, dan kepuasan kerja terhadap kinerja guru di SMP Negeri Kecamatan Sukasada Kabupaten Buleleng.

\section{DAFTAR PUSTAKA}

Agung, A.A. Gede, \& Sudiarta, Putu I Gusti. 2017. Developing School Management Model Based on Balinese Local Wisdom. Tersedia pada Advances in Social Science, Education and Humanities Research, volume 134. 2nd International Conference on Innovative Research Across Disciplines (ICIRAD 2017). Diakses 21 Januari 2018.

Agung, A.A. Gede. 2014. Metodologi Penelitian Pendidikan. Malang : Aditya Media Publishing.

Agung, A.A. Gede. 2009. Hubungan Kepemimpinan Transformasional, Kelelahan Emosional, Karakteristik Individu, Budaya Organisasi, dan Kepuasan Kerja dengan Komitmen Organisasional pada Guru SMA di Kota Denpasar. Disertasi. Malang: Program Pascasarjana, Universitas Negeri Malang.

Arikunto, S. 1998. Prosedur Penelitian: Suatu Pendekatan Praktek. Jakarta: Rineka Cipta.

As'ad. 2003. Kepemimpinan Efektif Dalam Perusahaan. Ed.2. Yogyakarta; Liberty.

Buchori, M. 1994. Spektrum Problematika Pendidikan di Indonesia. Yokyakarta: Tiarawacana.

Candiasa, I Made. 2011. Pengujian Instrumen Penelitian Disertasi:Aplikasi ITEMEN dan BIOSTEPS. Singaraja: Undiksha Press.

Candiasa, I Made. 2010. Statistik Univariat dan Bivariat:Disertai Aplikasi SPSS. Singaraja: Undiksha Press.

Dantes, Nyoman. 2012. Metode Penelitian. Yogyakarta: Penerbit Andi. 
Depdiknas. 2007. Pedoman Penjaminan Mutu Sekolah/Madrasah Bertaraf Internasional pada Jenjang Pendidikan Dasar dan Menengah. Jakarta

Gibson, J. L. dan Ivancevich, JM. 1996. Organizations: Behavior, Structure, and Process. Plano: Business Publication.

Hasibuan, M.S. 2002. Manajemen Sumber Daya Manusia. Jakarta: PT. Bumi Aksara.

Irianto, Agus. H. 2003. Statistik Konsep Dasar, Aplikasi, dan Pengembangannya. Jakarta: Kencana

Koyan, I Wayan. 2012. Statistik Pendidikan; Teknik Analisis Data Kuantitatif. Singaraja: Undiksha Press.

Kusuma., I.B. 2000. THK dalam Kehidupan Masyarakat Bali, makalah disampaikan dalam seminar THK pada tahun 2000, Pusaka, Denpasar.

Lantu, Donald, Erich Pesiwarissa, Agusman Rumahorbo. 2007. Servant Leadership. Yogyakarta: Gradien Books.

Margono, S. 2003. Metode Penelitian Pendidikan. Jakarta: PT. Rineka Cipta.

Muhadjir, 2000. Metode Penelitian Kualitatif. Yokyakarta: Rake Sarasin.

Mulyadi, Deddy. 2015. Perilaku Organisasi dan Kepemimpinan Pelayan (Konsep dan Aplikasi administrasi, Manajemen, dan Organisasi Modern). Bandung: Penerbit Alfabeta Bandung.

Mulyasa, 2003. Kurikulum Berbasis Kompetensi Konsep Karakteristik Implementasi. Bandung: Rosda Karya.

Nawawi, H. 1982. Organisasi Sekolah dan Pengelolaan Kelas. Jakarta: Gunung Agung.

Owens, R.G.1987. Organizional Behavior in Education. New Jersey. Prentice Hall Inc.

Peraturan Pemerintah Republik Indonesia Nomor 25 Tahun 2000 tentang Kewenangan Pemerintah dan Kewenangan Propinsi Sebagai Daerah Otonom.

Peraturan Pemerintah Nomor 19 Tahun 2005 Tentang Standar Nasional Pendidikan.

Peraturan Menteri Pendidikan Nasional Republik Indonesia Nomor 22 Tahun 2006 Tentang Standar Isi untuk Satuan Pendidikan Dasar dan Menengah.

Peraturan Menteri Pendidikan Nasional Republik Indonesia Nomor 23 Tahun 2006 Tentang Standar Kompetensi Lulusan untuk Satuan Pendidikan Dasar dan Menengah.

Peraturan Menteri Pendidikan Nasional Republik Indonesia Nomor 24 Tahun 2006 Tentang Pelaksanaan Peraturan Menteri Pendidikan Nasional Nomor 22 dan Nomor 23 Tahun 2006.

Peraturan Menteri Pendidikan Nasional Republik Indonesia Nomor 41 Tahun 2007 Tentang Standar Proses untuk Satuan Pendidikan Dasar dan Menengah.

Peraturan Menteri Pendidikan Nasional Republik Indonesia Nomor 19 Tahun 2007 Tentang Standar Pengelolaan. 
Prime, Ranchore. 2006. Tri Hita Karana Ekologi Ajaran Hindu Benih-benih Kebenaran. Surabaya: Penerbit Paramita.

Putra. 2005. Cudamani Kumpulan Kuliah-Kuliah agama Hindu. Bali: Kanwil Dep. Agama Provinsi Bali.

Robbins, S. P. 2003. Perilaku Organisasi, Edisi Indonesia. Jakarta: PT. Indek Kelompok Gramedia.

Robbins, P. \& Alvy, H. 2004. The New Principal's Fieldbook: Strategies for Success. Alexandria, Virginia USA: Association for Supervision and Curriculum Development.

Siagian, S.P. 2003. Teori dan Praktek Kepemimpinan. Jakarta: PT Asdi Mahayasa.

Snell, S. A. 1992. Control Theory In Strategic Human Resource Management: The Mediating Effect Of Administrative Information. Academy of Management Journal, 35, 292327.

Sonhadji, A. 1994. Teknik Pengumpulan Data dan Analisa Data dalam Penelitian Kualitatif. Malang: Kalimashada Press.

Suryabrata, Sumadi. 2002. Psikologi Pendidikan. Jakarta: Grafindo.

Susanto, Ahmad. 2016. Manajemen Peningkatan Kinerja Guru. Jakarta: Prenadamedia Group.

Tjahjono, H.K. 2006. Budaya Organisasional \& Balanced Scorecard: Dimensi Teory dan Praktik. Yokyakarta: UPFE-UMY.

Undang-Undang Republik Indonesia Nomor 22 Tahun 1999 tentang Pemerintahan Daerah.

Undang-Undang Republik Indonesia Nomor 20 Tahun 2003 tentang Sistim Pendidikan Nasional.

Undang-Undang Republik Indonesia Nomor 14 Tahun 2005 tentang Guru dan Dosen.

Wahab, A.A. 2008. Anatomi Organisasi dan Kepemimpinan Pendidikan: Telaah Terhadap Organisasi dan Pengelolaan Organisasi Pendidikan. Bandung: Alfabeta.

Wahab, Abd, \& Umiarso. 2011. Kepemimpinan Kependidikan dan Kecerdasan Spiritual. Yogyakarta:AR-Ruzz Media.

Werang, B. R. 2011. Faktor-faktor Penentu Kualitas Kinerja Guru. Malang: Penerbit Elang Mas.

Wiana, I Ketut. 2007. Tri Hita Karana Menurut Konsep Hindu. Surabaya: Penerbit Paramita.

Windia, W dan B. Ashrama. 2005. Mengukur Penerapan Konsep THK, dalam Buku Panduan THK Awards and Accreditation tahun 2005, Green Paradise. Denpasar.

Windia, W. dan Dewi, R.K. 2011. Analisis Bisnis berlandaskan Tri Hita Karana. Denpasar: Udayana University Press.

Yasmini, 2015. Kontribusi Gaya Kepemimpinan Kepala Sekolah, Kompetensi Profesional dan Motivasi Kerja Guru Terhadap Kinerja Guru-Guru Sekolah Dasar di Kecamatan Kuta Utara. Tesis tidak diterbitkan. Singaraja: Undiksha. 